\title{
Exporting People: The Philippines and Contract Labor in Palau
}

Dean Alegado and Gerard Finin

Long before reified notions of Southeast Asia and the Pacific Islands gained acceptance, seafaring peoples traveled and traded across areas that are today seen as bounded regional configurations. Interpretations of "differentness" were by no means tantamount to contemporary notions of "foreign." The emergence of colonial regimes, nation states, wage labor, and plantation agriculture has for well over a century contributed to the movement of "settler" populations to numerous Pacific islands (Denoon I997). During the nineteenth century, for example, marine produce such as turtleshell and bêche-de-mer was collected from Micronesia by ships based in Manila, where trade with China flourished. Ship crews composed of "manilamen" as well as individuals from other parts of Asia and the Pacific regularly visited Micronesian islands including Palau, and in several instances assisted western traders in establishing land-based operations for curing and commercial agricultural production (Hezel I983). While the presence of Filipino contract workers in Palau today may be seen as a continuation of these linkages, or yet another wave of Asian migration into the Pacific region (Connell I990), a number of distinctive elements are present in the contemporary movement of Filipinos to Koror and beyond. These distinctive characteristics raise important public policy issues as Palau looks toward the future.

To a far greater extent than any other independent Pacific Island nation, Palau has explicitly embraced the notion that "guest workers" are a critical ingredient of its national economic and social development strategy. Unlike other Pacific islands with significant populations of Asian ancestry such as Fiji and Hawai'i, the overwhelming majority of Filipinos in Palau were born and raised in the Philippines, giving rise to a seemingly plural society marked by largely separate communities within the same

The Contemporary Pacific, Volume I2, Number 2, Fall 2000, 359-370

(C) 2000 by University of Hawai' $i$ Press 
political unit (Furnivall I948). The growing presence of foreign laborers, together with Palau's free association status allowing its own citizens free entry to live and work in the United States, has created an anomalous situation for the Palauan labor force. Despite a rapidly expanding economy since gaining independence in I994, narrow employment opportunities, changing conceptions of work, and comparatively low wages are providing weak incentives for many young Palauans to remain in Palau and enter the private-sector labor market. ${ }^{1}$ Some believe that more than 50 percent of the private-sector labor force is currently composed of non-Palauan workers (PEDP I994, 80-83). ${ }^{2}$ Of the approximately six thousand nonPalauan workers in Palau, over 75 percent are from the nearby Philippines, suggesting an increasing level of dependency on guest workers that is unknown to other Pacific Island nations. ${ }^{3}$ To better understand these distinctive characteristics of contemporary Palauan society, it is useful to examine in broad terms the origins of Filipino migration to Palau, as well as how Palau is situated in the Philippines' labor-export industry and the global economy more generally.

\section{BACKGROUND}

The Philippines celebrated its independence from American colonial rule in 1946 at nearly the same time as Palau became part of the US-administered Trust Territory of the Pacific Islands. However, this common historical linkage to the United States is overshadowed by very different resource endowments and colonial histories. For example, the presence of natural resources such as gold and a land area that could support large-scale plantation-style agriculture made the Philippines important to world export markets. In contrast, Palau's attractiveness in recent years as an international tourist destination is largely attributable to its small size, lack of industrial development, and unspoiled natural beauty. The postindependence decision to make Asian-led tourism the engine of Palau's economic growth during the I990s has resulted in both a construction boom fueled by foreign capital and a burgeoning service sector composed primarily of Filipino contract workers, who number over 4,500 in a population of some I 8,000 (Bank of Hawaii I997, 4).

Filipino contract workers have been present in Palau for more than thirty years. In the early I960s skilled Filipino construction crews were brought via Guam to build a hospital and a communication center, among other structures. Shortly thereafter, lay missionaries and teachers came to support the Catholic mission. Filipino construction workers were again 
brought to Palau following the devastation caused by Typhoon Sally in 1967. With assistance from the US Department of the Interior, numerous post-typhoon infrastructure projects were undertaken by local construction firms that hired Filipino workers on a temporary basis. Once these projects were completed, the workers left Palau. At the same time, a number of Filipinos were recruited to fill teaching and other professional positions. By the early r970s some two hundred Filipinos were working in Palau, and a nascent community organization had formed. Within a decade this number grew to over five hundred, with a sizable number of Filipino seamen recruited to work in the expanding fishing industry.

The second phase of Filipino migration began in 1984, when Air Nauru inaugurated flights between Manila and Palau. This direct link brought hundreds of Filipinos to Koror each month. In an intriguing twist, many Palauans began to view the Philippines as a more advanced metropolitan country, traveling to Manila for higher education, medical care, shopping, and recreation. Yet during the same period, as commercial air service expanded, an increasing number of Filipino contract workers, many possessing college degrees and professional experience, began arriving from the metropolis for low-paying employment as service workers. What made Palau distinctive as a destination was that the Philippine nation came to be seen by Palauans as a place that was significantly "more developed" than their own nation, while Filipinos as a people were perceived as a social group willing to work under the supervision of Palauans for comparatively low wages. These contract workers were predominantly young women hired as live-in domestic helpers, waitresses, and entertainers. Among Filipino men in Palau, most came to work in the construction and service industries. As the private sector has increasingly relied on Filipinos and other foreign guest workers, who now constitute approximately onethird of Palau's total population, Palauans have experienced changes that have at once produced benefits while also creating tensions.

From the perspective of Palauan employers, Filipinos are often said to be more reliable because they report for work on a regular basis and do not take time off for family or community related cultural activities. This preference, in turn, has created resentments among Palauan employees who do not understand the similar responsibilities borne by Filipinos when residing in their own communities. Similarly, what is seen as Filipinos' propensity to overexploit Palau's natural resources engenders antipathy, which is exacerbated when Filipino fishing vessels lacking necessary permits are apprehended in Palau's exclusive economic zone (PDI, 20 Feb, 29 Nov 1998). Palauans use of the term chad ra Oles (literally, "people 
of the knife") to refer to Filipinos suggests the frictions that have arisen in recent years. ${ }^{4}$ Filipinos' view of their treatment by Palauans, while for the most part favorable, is not without criticisms. Human rights reports make note of incidents of alleged mistreatment of foreign workers in Palau, including "physical and verbal abuse, working overtime and on days off without pay, withholding monthly salary, deductions from monthly salary for the amount of airfare, and substandard housing" (USDS 1999). While some suggest that tensions between Palauans and Filipinos may be easing, based in part on the establishment of diplomatic relations and the opening of a Philippine embassy in Koror in I998, there remains considerable room for improvement.

\section{Exporting People}

The growth of Filipino labor in Palau parallels state-supported efforts by the government of the Philippines to implement a labor-export strategy that encouraged the movement of millions of Filipinos to all corners of the globe. The strategy initially focused on tax incentives for Philippine firms in the late I970s, with the government formally promoting trade in "manpower services" in the early I980s. The exit of unemployed and underemployed youth streaming out of Manila's universities coupled with a steady flow of remittances to support family members back home were but two of the reasons labor export was seen as an attractive option. The Philippine Overseas Employment Administration, founded in I982, promotes and regulates labor export, though informal and illegal recruitment has always been a large part of this endeavor. Goss and Lindquist suggest the scale of this activity, noting that by the mid I990s there were an estimated 6 million Filipinos working overseas in I30 different countries, of whom 4I percent were legal contract workers, 30 percent undocumented workers, and 29 percent settlers (this issue). This rise of the Philippines as a major labor-exporting state is linked to both global spheres of production and internal sociocultural factors, which in certain regions include time-tested traditions of trying one's luck to "make good" abroad. ${ }^{5}$

Palau is by no means the only country to see foreign labor as an important component of national development. Some labor-importing countries such as Brunei and Saudi Arabia have encountered a general labor shortage following the discovery of a valued natural resource such as oil. As these countries have used their newfound wealth to build and modernize their economies they have overcome domestic labor shortages by looking toward areas of the world where labor surpluses exist (Martin 1996). In 
addition to a general lack of workers, certain countries have found that their domestic labor force does not possess sufficient education or the training required for technical fields of employment. Workers ranging from professional managers to technicians and laborers are needed, for instance, to operate transport and communication systems. Global competition, as well as increased integration into the global economy, also plays an important role in the utilization of foreign labor. Local elites and transnational firms often seek low-cost labor from abroad to minimize labor costs. Pierantozzi details elsewhere in this issue how, for labor-importing countries like Palau, foreign labor is viewed as an attractive short-term means to achieve ambitious long-term national development goals.

Such observations underscore how foreign labor has frequently been important in the early stages of the capital accumulation process, or in areas of production that require large pools of service-industry labor. Agriculture, hotel, restaurant, and garment manufacturing are but a few of the economic activities falling under this rubric. In addition, the cost of training migrant workers is absorbed by the sending country, suggesting that this transfer of "social capital" is an immediate net gain for the laborimporting country. Still, contract or guest workers often form the most exploited, least privileged stratum of the working class employed in such circumstances. To the extent that contract workers lack political rights and are fleeing from poverty and unemployment, their vulnerability renders them docile and, therefore, dependable. In some countries migrant guest labor may provide a way for the state to avoid pressure from organized native-born labor by placing them in competition with those brought in from the outside.

\section{Palau as a Plural Society?}

The social implications for the host society that relies on large numbers of guest workers vary considerably. There are, however, experiences in other parts of the Pacific and Asia that may offer useful insights for assessing Palau's situation today. In his classic study of colonial Burma, John Furnivall analyzed how a plural society had been created, wherein different sections of the community lived side by side, but separately, within the same political unit. "It is in the strictest sense a medley," argued Furnivall, "for they mix but do not combine. Each group holds by its own religion, its own culture and language, its own ideas and ways." With a division of labor along "racial lines," and society lacking the qualities of an organic whole, he lamented how transient workers in Burma "come merely to 
make money and their interest in the country is purely economic. In a plural society the union is not voluntary but is imposed by ... the force of economic circumstances and the union cannot be dissolved without the whole society relapsing into anarchy" (1948, 304-306). While Furnivall's conception of the plural society risks essentialization of complex economic specialization, social differentiation, and ethnic relations, it is valuable as a heuristic concept to advance our analysis.

Based on observations in and around Koror, indicators suggest that Palau is gradually assuming a number of characteristics that Furnivall attributed to the existence of a plural society in Burma. Legal structures, for example, place limitations on the degree to which non-Palauans can participate in and become part of Palauan society. As is true in many Pacific Island nations, the process of naturalization for gaining citizenship is extremely restrictive. In a similar manner, the laws of Palau are very explicit that non-Palauan ownership of land on a fee-simple basis is not allowed. Social conditions as evinced in everyday life also suggest a plural society may be emerging in Koror. One of the most visible indications of a rather sharp division of labor, as noted previously, is the extent to which the private sector appears to be heavily dominated by "guest workers" and the public sector appears to be dominated by Palauans. Some of these guest workers talk about life in the segregated barracks where foreigners are apt to reside. The 1999 implementation of a minimum-wage law that explicitly excludes foreign workers provides further evidence of a divide that gives legally sanctioned incentives for the private sector to hire lessexpensive, non-Palauan employees. ${ }^{6}$ To the extent that manual labor, and especially agricultural labor, is increasingly coming to be seen in Palau as something within the exclusive domain of "foreigners," there is growing evidence that younger Palauans' traditional conceptions of work and the socioreligious dimensions of activities related to agriculture may be changing in significant ways. ${ }^{7}$ Visits to Palau suggest still other ways in which a plural society is emerging. As a means of ensuring that employment opportunities exist, certain occupational permits, such as taxi drivers' licenses and boat tour operators' permits, are limited to Palauans. In the late I990s it was reported that the Koror state legislature had passed legislation limiting non-Palauans' access to certain areas of the Rock Islands (PSN, 26 April 1998). Perhaps most visible to even the casual observer are the large numbers of Filipinos strolling around Koror's stores and markets following the Sunday church services. By early Sunday afternoon, certain sports centers and clubs become entirely Filipino-reportedly the only 
time when managers allow Filipino bands to play songs in their national language.

While these observations suggest Palau may increasingly resemble preindependence Burma, with economic-based, bounded, and at times conflict-prone relations among various groups, closer examination provides some evidence to the contrary. Such evidence clearly challenges certain elements of the plural-society construct. Perhaps the strongest evidence suggesting that relations between Palauans and foreign workers do extend beyond the economic sphere is found by analyzing the role played by the large number of domestic helpers. Unlike their counterparts in the Philippines, who often have a pronounced degree of specialization as household yaya (nannies), labandara (washerwomen), or kitchen workers, domestic helpers in Palau tend to be all-round workers who for approximately \$ Ioo per month plus room and board provide a full range of help in hundreds of Palauan homes. ${ }^{8}$ Usually residing in the house of the employer, the domestic helper's services include but are not limited to cooking, cleaning, gardening, and child care. It also appears that Filipinos are actively engaged in what for many Palauans are culturally significant agricultural tasks, such as planting taro and preparing pigs for feasts. With this high degree of close day-to-day interaction with Palauan families, it is all but impossible to avoid some level of integration and assimilation above and beyond that of a hired wage employee.

Interviews with domestic helpers about daily life in Palau strongly suggest that most have to varying degrees become members of the extended family household in which they are employed. Given that many of them acquire a high degree of fluency in the Palauan language as spoken in Koror, it is clear that the socially bounded or stratified "medley" described by Furnivall, with each group strictly adhering to their own language and broader set of cultural norms, is gradually breaking down as larger numbers of domestic helpers and other guest workers stay in Palau for extended periods. ${ }^{9}$ Indeed, recent changes to Palau's immigration statutes, easing the entry of foreign workers' spouses and children, provide further evidence of long-term settlement and acculturation.

Data from the Immigration and Customs Division as well as from interviews provide evidence that further destabilizes the view of Palau as a fully plural society. As of the mid I990s, at least one hundred non-Palauans, of whom approximately 50 percent were Filipinos, were married to Palauans. Anecdotal evidence indicates some "common law" household arrangements may exist as well. From these unions a group of individuals 
variously termed hapa, mestizo, or half-caste is gradually emerging in Palauan society. As progeny of both Palauan and Filipino parentage, these young people are changing the way people view Palau's ethnic grid and have the potential to play a very influential role in the nation's future. The unions also underscore the time-tested axiom that nothing is as permanent as a temporary worker.

\section{CONCLUSION}

Several features of the non-Palauan labor force in Palau make the Pacific region's youngest nation distinctive. The scale of migration in terms of the percentage of contract workers as a proportion of the total workforce, arriving over a brief period of time, has resulted in a transformation of the population profile that is unprecedented among postindependence Pacific Island nations. With growing numbers of guest workers who tend to limit opportunities and wages for many Palauans, Palau is also distinctive in terms of the percentage of citizens who, despite a growing domestic economy, are migrating to the United States. The export of Filipino workers from the Philippines to Palau appears to have encouraged the departure of Palauan workers seeking better wages and opportunities (Endo I997).

Understanding the logic that drives Palau to encourage the inflow of guest workers while restricting the range of rights and opportunities extended to non-Palauans calls for analysis of both internal and external forces. Restrictions on guest workers acquiring citizenship, for instance, has its genesis in an appreciation of historical forces in the Pacific Islands. Palauans' experience under Japanese rule, when they became a numerical minority in the presence of some twenty-seven thousand Japanese citizens, helps to explain why Palau is wary of opening its doors to unrestricted permanent entry by people from around the globe. Other evidence pointing toward the emergence of a plural society may also, on closer examination, have a rationale different from that offered by first impressions. For example, the law restricting use of certain areas of the Rock Islands to Palauans was for many individuals not an issue of exclusivity based on nationality, but an attempt to protect a very precious environmental resource from being overrun by tourists.

Aside from the legitimate desire of Palauans to retain control of their nation through limitations on acquisition of citizenship, prohibition of land sales to non-Palauans, and so on, there is perhaps a more fundamen- 
tal explanation for Palau's movement toward a society embracing plural features. Given the highly competitive nature of the tourism industry, it should come as no surprise that Palauans heeding the call by international development institutions to develop their private sector have done so in a manner consistent with the fundamental principles of private enterprise. Minimizing costs would certainly stand as one of the most essential principles, especially with regard to labor. If the law allows wages of \$ Ioo or \$I50 per month for guest workers, it would be highly unusual for a firm to voluntarily pay substantially more to Palauan workers.

A free and unfettered business environment congenial to global economic forces is said by many development specialists to provide the most direct path to developing an economy that will sustain a high standard of living. However, a critical role of public policy is to guide society toward a desired quality of life that is consistent with peoples' aspirations and in harmony with cultural and environmental endowments. Public officials and policymakers in Palau are certainly well aware of the challenges associated with adopting policies to advance these goals. There is increasing recognition of the need for policies that will avoid further fissures or polarization between elements of Palau's workforce. What were once seen as highly temporary measures to supplement Palau's labor force are increasingly analyzed in terms of future long-term needs.

The heavy dependence on temporary workers has raised serious concerns in Palau regarding whether this trend may already have compromised the country's capacities for self-reliance. Has Palau as a nation become too heavily dependent on non-Palauans? One way of thinking about this issue is to ask what would happen in Palau if guest workers stopped working for a day, a week, or a month? The growing influence of global forces in Palau, as evinced by Filipino contract labor and the emergence of a society with an increasing number of plural features, has encouraged considerable public discussion and debate. Palau's Vice President Tommy Remengesau articulated the potential dangers of "a clear and straight path toward rapid development" when he noted in a 1997 public address at Palau Community College that such an approach could "lead us to short term wealth at the expense of our culture, our environment and our national identity." 10 To the degree that policymakers continue to demonstrate an openness to learning from recent experiences, there is reason for optimism as the world's youngest nation charts its course over the next decade. 
Notes

I Palauan out-migration stands at some 7,000 (CoPopChi 1997, 9). According to the Palau Economic Development Plan, in I980 fully 84.6 percent of the work force was Palau-born, but this percentage decreased to 66.3 percent in I990, a decrease of nearly 20 percent in one decade. The percentage of Palauborn managers and professionals decreased from 85 percent of the workforce in I980 to 80 percent in I990, and those in technical, sales, and administrative support occupations decreased from 93 percent to 87 percent. Notably, the service sector showed the greatest change: Palau-born constituted 92 percent of that sector in I980, but only 57 percent in 1990 (Palau I994, 8I).

2 Additional data are required to confirm this estimate.

3 These and subsequent figures were derived from the CoPopChi report (1997) and interviews with Immigration and Customs Division officials. Although not an independent nation, the US Commonwealth of the Northern Mariana Islands may for the near term be seen as an exception to this statement.

4 Several Palauans noted that prior to the I960s some people referred to Filipinos as chad ra Huriping or people from Huriping. During the I960s and I970s the terms chad ra Mekedorm (literally "people of the sharp objects") and chad ra Oles became more common. Filipinos are said by some Palauans to have an affinity for using sharp objects as weapons during altercations.

5 The Philippine Daily Inquirer (26 Sept 1998) quoted a statement by the governor of the Central Bank noting that Filipino overseas contract worker remittances for 1998 through official banking channels were estimated to be over $\$ 6$ billion. Another \$I billion was expected to enter the country through "informal" channels, making remittances the biggest source of foreign exchange for the country.

6 One local business owner, Philip Reklai, summarized the consequence of imposing a \$2.50 minimum-wage law for Palauans this way: "It will hit me directly, so what do I do? I fire the Palauan and hire a Filipino for \$I.5O an hour. I have to. I am a businessman" (PIR, 7 Jan I999 <http://pidp.ewc.hawaii.edu/ pireport/>).

7 Nero, Brel Murray, and Burton have provided the most systematic analysis of these changes (this issue). The growth of commercial agriculture has brought about the creation of some five hundred jobs for agricultural workers in recent years. However, extremely few of these positions are held by Palauans. The same basic picture is found in the vocational trades, despite the presence of collegelevel educational programs in both agriculture and vocational trades.

8 It has been hypothesized that the presence of domestic helpers may weaken the role played by the extended families in Palau, most notably for single mothers who have the means to hire one or more such live-in helpers. We are indebted to Francis X Hezel, SJ, for this insight. 
9 The number of Palauans who comprehend and in some cases speak Filipino also appears to be growing.

Io Remarks of Vice President Tommy E Remengesau, Jr at the Moving Cultures colloquium, Palau Community College, Koror, 5 Nov 1997. <http://www. hawaii.edu/movingcultures/>

\section{References}

Bank of Hawaii

I997 Republic of Palan Economic Report. Honolulu: Bank of Hawaii Economics Department.

Connell, John

I990 The Last Wave: Filipino Labor Migration to the Pacific. In Labour in the South Pacific, edited by Clive Moore, Jacqueline Leckie, and Doug Munro, I 28-I32. Townsville: James Cook University of North Queensland.

CoPopChi, Palau National Committee on Population and Children

1997 Population and Development: Toward a Palau National Policy for Sustainable Human Development. March. Koror: Office of the President.

Denoon, Donald, editor

1997 The Cambridge History of the Pacific Islanders. Cambridge: Cambridge University Press.

Endo, Hiashi

I997 The Meaning of Palauan Population Movement: An Analysis of Life Histories. In Contemporary Migration in Oceania, edited by Ken'ichi Sudo and Shuji Yoshida, 25-44. Osaka: Japan Center for Area Studies, National Museum of Ethnology.

Furnivall, John S

I948 Colonial Policy and Practice. Cambridge: Cambridge University Press. Hezel, Francis X, SJ

1983 The First Taint of Civilization: A History of the Caroline and Marshall Islands in Pre-Colonial Days, I52 I-I885. Pacific Islands Monograph Series I. Honolulu: Center for Pacific Islands Studies and University of Hawai'i Press.

Martin, Philip

1996 Migrants on the Move in Asia. Asia Pacific Issues Paper 29. Honolulu: East-West Center.

Moore, Clive, Jacqueline Leckie, and Doug Munro

1990 Labour in the South Pacific. Studies in Melanesian History. Townsville: James Cook University of North Queensland. 
Palau, Republic of

I994 Economic Development Plan: Fiscal Years I995-I 999. Two volumes. Koror: Government of Palau.

PDI, Philippine Daily Inquirer. Manila.

PSN, Pacific Sunday News. Koror. Weekly.

Sudo, Ken'ichi, and Shuji Yoshida, editors

1997 Contemporary Migration in Oceania: Diaspora and Network. Osaka: Japan Center for Area Studies, National Museum of Ethnology.

USDS, US Department of State

I999 Palau Country Report on Human Rights Practices, I998. Released on Internet by Bureau of Democracy, Human Rights, and Labor, Washington, DC. <http://www.state.gov/www/global/human_rights/I998_ hrp_report/palau.html> 